\title{
Assessing the Performance of Students in Communication Skills: A Case Study of Two Public Universities in Sierra Leone
}

\author{
John Dauda ${ }^{1}$ and Steven Sylvester Bockarie ${ }^{2} \square$ \\ ${ }^{12}$ Language Studies Department, Faculty of Education, Eastern Technical University, Sierra Leone \\ $\square$ Corresponding Author: Steven Sylvester Bockarie, E-mail: bockariesteven@yahoo.com
}

ARTICLE INFORMATION ABSTRACT

Received: 08 October 2021

Accepted: 07 November 2021

Published: 18 November 2021

DOI: 10.32996/ijels.2021.3.11.4

\section{KEYWORDS}

Communication skills, Competence and performance, Pedagogical capabilities, Teaching and learning
The purpose of this study is to assess the performance of students in Communication Skills in two tertiary institutions in Sierra Leone - the Eastern Technical University and the Njala University. The introduction of Communication Skills into the curriculum of teacher training institutions is viewed as a reaction to the poor performance of students in the written and spoken use of the English Language. However, the introduction of Communication Skills at tertiary institutions is yet to remedy the situation. To guide the study properly, some objectives were developed. These include; an investigation of the extent to which English is used by lecturers and students in the institutions, an examination of students' attitude towards the learning of Communication Skills, an investigation to time allocation to the teaching of the subject, and an examination of the pedagogical capabilities of the Language studies departments of both institutions with regards their personnel, teaching methodologies, and the teaching/learning resources. The result of the study revealed the following: that students speak English seldom in class and within the campus and also very seldom in their homes; that Krio and other Sierra Leonean languages are widely spoken in these institutions as does the English Language; that the credit hours allocated to the teaching of the subject is insufficient; that students find some aspects of Communication Skills Challenging; and that although both institutions have general libraries, these libraries are not very well stocked with English textbooks.

\section{Introduction}

English is the official language used in all forms of formal communication and business communication in Sierra Leone. This official use of English as a medium of communication cannot be unconnected from the fact that Sierra Leone was colonized by the British, who used English as their first and official language. English is therefore taught as a compulsory subject at all levels in the primary and secondary schools in Sierra Leone.

The official aim of such curriculum design is to capacitate every school-going pupil with some literacy skills in the English Language. The intention of acquiring such skills is to enable the students to communicate effectively in all forms of formal situations at national and international levels.

In this regard, Language Arts and English Language are taught as core subjects at the junior and senior secondary schools respectively. It is emphasized at the end of these levels that, a pass in Language Arts at the Basic Certificate Examination (BECE), is an ultimate requirement for entrance in the senior secondary school and some technical and vocational institutions.

Similarly, a credit in the English Language at the West African Senior Secondary School Certificate Examination (WASSCE) is a major requirement for admission into the university, polytechnic, and Teacher Training Colleges in Sierra Leone.

Copyright: (c) 2021 the Author(s). This article is an open access article distributed under the terms and conditions of the Creative Commons Attribution (CC-BY) 4.0 license (https://creativecommons.org/licenses/by/4.0/). Published by Al-Kindi Centre for Research and Development, London, United Kingdom. 
Certainly, these entrance requirements at the end of these various levels of schooling are a pointer to the fact that every Sierra Leonean school-going child is expected to exhibit some amount of proficiency in English before proceeding to any other stratum of the academic ladder.

Furthermore, Communication Skills has been introduced into the curriculum of tertiary institutions in order to establish some continuity in the studies of English. The introduction of this course as a component of the English Language in the universities, polytechnics, and teacher training colleges is intended to strengthen students' communicative skills; especially for those who might not opt to study English as a specialist course. It is also viewed as a reaction to revitalize students' poor performance in English at tertiary institutions. Therefore, Communication Skills is considered as a compulsory course at certain levels in these tertiary institutions irrespective of the student's area of specialization.

The overall aim of teaching Communication Skills at tertiary institutions is to enable students to acquire adequate competence and subsequently perform better in English. This performance does not just limit itself to examination purposes, rather for effective communication in the fields of politics, academia, socio-economic, and research purposes.

The pedagogical approach, therefore, incorporates the teaching and learning of the four language skills of Listening, Speaking, Reading, and writing as driving forces in the realization of the aims and objectives of teaching Communication Skills at tertiary institutions.

In spite of these varying approaches used in the teaching and learning of the subject, its intended purposes are far from being realized in these institutions. As a result, there are growing concerns over the poor performance of students in Communication Skills over the years. This has been attributed to several factors amidst varying points of view.

This study is therefore intended to investigate the factors that are responsible for the poor performance of students in Communication Skills at tertiary institutions. A case study has been made with selected students of the Higher Teachers Certificate (Primary) and selected lecturers of Communication Skills in two tertiary institutions in Sierra Leone.

\subsection{Statement of Problem}

The drastic fall in students' performance in Communication Skills is not only evident in their unsatisfactory reading, speaking, and writing abilities, but it is also evident in their horrible performance in both internal and external examinations.

\subsection{Aim and Objectives of the Study}

The aim of this study is to assess the performance of students in Communication Skills at tertiary institutions in Sierra Leone.

The objectives include the following:

- Investigate the factors that contribute to students' poor performance in Communication Skills

- Examine the attitude of students towards the teaching and learning of Communication Skills

- Investigate the pedagogical capabilities of the Language Studies Department of the targeted institutions

- Proffer relevant recommendations based on the findings of the study.

\subsection{Significance of the Study}

This study will unravel the factors responsible for the poor performance of students in Communication Skills at tertiary institutions and suggest strategies to remedy the situation.

\section{Review of Literature}

Although there is relatively little literature available on students' performance in communication, the researchers however made a careful selection of materials including reports on researches, textbooks, journals, and encyclopedias. They include the following:

Chomsky (1965) produces a much more formal explanation of language learning in his famous theory of 'Competence and Performance'.

He thus made a fundamental distinction between competence (the speaker - hearer's knowledge of his or her language) and performance (the actual use of language in concrete situations).

Chomsky's initial concern was with the native language of the speaker but has come to have considerable significance in second language learning. In this respect, competence can therefore be described as the linguistic knowledge of fluent speakers of a language. Since competence is an abstract concept, it can only be meaningfully evaluated through the observation of the speaker's or writer's performance of his or her competence. 
Performance in Chomsky's view is of immense significance in the language learning process; in that, it helps the teacher to determine:

$>\quad$ The knowledge level of the learner.

$>$ The aspect(s) in a language that the learner finds difficult to grasp.

$>$ The remedial pedagogical steps to be taken by the teacher to help the learner improve on his or her performance.

Bachman (1990) in his studies of second language testing states that one way in which a student teacher can begin to acquire action (system knowledge) is through guided, systematic and focused observation of experienced second language teachers. Such a process according to him, will aid the student-teacher in conceptualizing what goes on in the second language classroom. He further stresses that having a formal program of observation can assist the student-teacher in the following:

$>$ Developing a terminology for understanding and discussing the teaching process.

$>$ Developing an awareness of the principles and decision making that underlie effective teaching

$>$ Distinguishing between effective and ineffective classroom practices.

$>$ Identifying techniques and practices student teachers can apply to their own teaching of language.

Crystal (1987) asserts that the most obvious way of reducing some of the powers of the language barrier is to promote the teaching and learning of foreign languages in a variety of child and adult educational settings. According to him, this widely practiced approach is undoubtedly proving to be successful as can be judged by the millions who succeed in mastering a foreign language. Crystal also explained that there is also a great deal of educational failure and lack of achievement in the language-learning field. Although many have tried to learn a foreign language, (like English), they have made little progress in it.

"It is therefore important to study the factors that govern success or failure in this field" (Crystal 1987:368)

Crystal further highlights some of the factors that govern success or failure in the teaching and learning of English as a foreign or second language. This he said includes.

- The soundness of the teaching method

- The attitude and motivation of the learner

- The availability of the time and opportunities to learn.

- The adequacy of resources

- The chance to put the language to active use

Crystal further explains the concept of the teaching and learning of English as a foreign language. According to him, the concept of 'Foreign Language Teaching' (FLT) and 'Foreign Language Learning' (FLL) reflects an important development in the modern study of the subject. In his view, foreign language teaching was thought at one time, to be exclusively a matter of teaching techniques; it was felt that, if teaching was above a certain level of efficiency, learning would atomically follow. Teaching, according to him, was the active skill; while learning the passive one. Crystal added that the role of learners today is an established principle.

He emphasizes the existence of glaring individual differences among learners especially in personality and motivation which in his view directly influence the teaching outcome. He concluded that people are seen to be largely responsible for their own progress. As he puts it:

"Research is therefore now directed not only at the way teachers teach but also at the way learners learn "(Crystal 1987:368)

Bright (1995), in his studies of second language learning, reports that English as a second language cannot take place without exposure to a certain teaching situation. According to him, it may be salutary to consider the kinds of English to which pupils are normally exposed and what therefore they have the opportunity to learn. He further maintains that exposure need not, of course, be limited to classroom situations, and what happens outside may be important. But in most cases, it is what is done in the classroom that will have the greatest effect.

Bright further states that, in the teaching and learning of English as a foreign or second language, we cannot of course get out of the classroom situation or use language in ways unnatural to the teaching situation, but we must provide adequate exposure to other models in other situations. Some of these situations can be provided in the classroom but most of the exposure to language at a higher level must take place through the reading of texts nearly all new learning will take place while the student is reading. The field in which he or she reads will determine the language he or she learns.

Textbooks are the single most used instructional tool in the classroom. 
The textbook has had the longest and most obvious influence on curriculum, to the extent of, on effect, standardizing teaching and instructional practices (Ornstein 1992:167).

Textbooks according to Ornstein provide a common resource for all students. Most English textbooks he adds include pictures and illustrations that facilitate learning and that, the reading levels and knowledge base of most textbooks match the developmental level of the student.

The implication here is that a greater percentage of students are not exposed to reading materials.

Critics of textbook usage, on the other hand, claim that the quality of the textbooks is not as good as it could or should be.

"Textbooks summarize large quantities of information and often make it too general and superficial this discouraging conceptual thinking, critical analysis, and evaluation" (Woodward and Elliott 1990:183).

Tucker (2006) in her studies on the impact of Krio on the learning of English as a second language reveals that the teaching and learning of English are greatly affected by the Krio background of the students. According to her, Krio affects students' use of English in both the spoken and written forms resulting in incorrect and substandard forms of language use.

In her view, students' performance in English is been hindered by four forms of errors as a result of the interference of Krio into written and spoken English. These errors include:

$>$ Spelling errors

$>$ Vocabulary errors

- Grammatical errors (structure, tense, syntax, and sentence pattern)

$>$ Speech errors.

Most lecturers assessing students' performance in communication skills have noted in support of Tucker's research that these errors are common occurrences in students' written and spoken English. Most English words are wrongly written and spoken due to the lack of recognition or realization of the differences between Krio and English. The idea is that most students use English words but with substandard pronunciation. Therefore, when they write and pronounce such words they tend to base their spellings and utterances on the Krio pronunciation. The most commonly used speech error is the use of short vowels in place long vowels; which to a large extent affects the correct pronunciation of most English words.

Ozarska (2008) in a research on the academic writing instruction at English Teacher Training Colleges reports that continuous writing (essay, letter, report, minutes, and memorandum writings) forms the crust in determining the extent to which students perform in English at tertiary institutions.

According to her, learning to write in an academic context in English is a tremendous challenge for students because to master the writing style requires an understanding of an academic text's logic, structure, and formal vocabulary. As she puts it:

"At the advanced level, it takes a large investment of class time to reach the point where teacher trainees are able to use rhetoric and mechanics to write quality academic texts, including argumentative, persuasive, expository, and technical essays" (Ozarska, 2008:30).

3. Methodology

3.1Population

The population of the study included students of the Higher Teachers Certificate (Primary) of the two institutions: Eastern Technical University and Njala University.

\subsection{Sample and Sampling Technique}

One hundred and forty students were selected from both institutions; each institution was represented by seventy students. Ten lecturers were also selected for the study. Five lecturers were selected from each of the target institutions.

\subsection{Instruments for Data Collection}

Two sets of structured questionnaires were designed for the research. One set of questionnaires was prepared for the students and another set for the lecturers of Communication Skills. 


\subsection{Method of Data Collection}

The researchers used well-structured questionnaires, focus group discussions, informal interviews, personal experience, and institution records to collect the required data.

\subsection{Method of Data Analysis}

In the presentation and analysis of data for the study, tables were used to illustrate the findings. Also, the four- points rating scale was used to analyze the data collected for the study.

\section{Result and Discussions}

Table 1 How often do you speak English?

\begin{tabular}{|l|l|l|l|l|}
\hline & \multicolumn{2}{|l|}{ Eastern Technical University } & Njala University \\
\hline & No. & \% & No. & $\%$ \\
\hline Very often & 05 & 7 & 10 & 14 \\
\hline Often & 06 & 9 & 12 & 17 \\
\hline Seldom & 42 & 60 & 30 & 43 \\
\hline Very seldom & 17 & 24 & 18 & 26 \\
\hline Total & $\mathbf{7 0}$ & $\mathbf{1 0 0}$ & $\mathbf{7 0}$ & $\mathbf{1 0 0}$ \\
\hline
\end{tabular}

Table one explains how often students speak English. In spite of the fact that Higher Teachers Certificate (Primary) students speak other languages most often to communicate, they however use English at certain percentages. According to table one, 05 (7\%) students at the Eastern Technical University speak English very often while 10 (14\%) at the Njala University speak English very often. Also, 06 (9\%) and 12(17\%) students speak English often at Eastern Technical University and Njala University respectively. The table further explains that $42(60 \%)$ students at the Eastern Technical University and $30(43 \%)$ students at the Njala University speak English seldom. And finally, according to table one, 17 (24\%) students speak English very seldom and at the Eastern Technical University and 18 (26\%) students speak English very seldom at the Njala University. The result reveals that there are a greater number of students in both institutions who either speak English seldom or very seldom. This indicates that students very often speak another language apart from English. This to a large extent could be a contributing factor to the students' lack of fluency in English since everybody becomes fluent by speaking.

Table 2: Lecturers of communication skills have adequate Knowledge in their subject area

\begin{tabular}{|l|l|l|l|l|}
\hline & \multicolumn{2}{|l|}{ Eastern Technical University } & \multicolumn{2}{l|}{ Njala University } \\
\hline & No. & \% & No. & \% \\
\hline Strongly agree & 52 & 74 & 40 & 57 \\
\hline Agree & 14 & 20 & 25 & 36 \\
\hline Disagree & 04 & 6 & 05 & 7 \\
\hline Strongly disagree & - & - & - & - \\
\hline Total & $\mathbf{7 0}$ & $\mathbf{1 0 0}$ & $\mathbf{7 0}$ & $\mathbf{1 0 0}$ \\
\hline
\end{tabular}

Table two shows the extent to which Communication Skills lecturers have knowledge in their subject area. This knowledge is indicated in table two. According to the table, 52 (74\%) students at the Eastern Technical University and 40 (57\%) at the Njala University strongly agreed that their Communication Skills lecturers have adequate knowledge in their subject area. Also, 14 (20\%) at the Eastern Technical University and $25(36 \%)$ at the Njala University agreed that their Communication Skills lecturers have adequate knowledge in their subject area. The table further shows that 04 (6\%) and 05 (7\%) students at the Eastern Technical University and Njala University respectively disagreed that their Communication Skill lecturers have adequate knowledge in their subject area. The result here shows that in spite of students' poor performance in Communication Skills, their lecturers have adequate knowledge in their subject areas as shown in table two. 
Table 3: Lecturers have adequate motivating skills in teaching communication skills

\begin{tabular}{|c|c|c|c|c|}
\hline & \multicolumn{2}{|c|}{ Eastern Technical University } & \multicolumn{2}{|c|}{ Njala University } \\
\hline & No. & $\%$ & No. & $\%$ \\
\hline Strongly agree & 17 & 24 & 18 & 26 \\
\hline Agree & 45 & 64 & 42 & 60 \\
\hline Disagree & 08 & 12 & 10 & 14 \\
\hline Strongly disagree & - & - & - & \\
\hline Total & 70 & 100 & 70 & 100 \\
\hline
\end{tabular}

Table 3 shows students' responses that lecturers have adequate motivating skills in teaching Communication Skills. The table indicates that 17 (24\%) at the Eastern Technical University and 18 (26\%) at the Njala University, strongly agreed that their lecturers of Communication Skills have adequate motivating skills in teaching their subject areas. It is also indicated by 45 (64\%) and 42 (60\%) who agreed that their lecturers have adequate motivating skills in teaching Communication Skills at the Eastern Technical University and Njala University, respectively.

However, $08(12 \%)$ and 10 (14\%) students disagreed that lecturers have adequate motivating skills in teaching Communication Skills at Eastern Technical University and Njala University, respectively.

The result according to table three reveals that lecturers have adequate motivating skills in teaching Communication Skill although smaller percentages disagreed.

Table 4 Lecturers are skillful in handling problems in communication skills

\begin{tabular}{|l|l|l|l|l|}
\hline & Eastern Technical University & \multicolumn{2}{l|}{ Njala University } \\
\hline & No. & \% & No. & \% \\
\hline Strongly agree & 30 & 43 & 20 & 28 \\
\hline Agree & 39 & 56 & 48 & 69 \\
\hline Disagree & 01 & 1 & 02 & 3 \\
\hline Strongly disagree & - & - & - & \\
\hline Total & $\mathbf{7 0}$ & $\mathbf{1 0 0}$ & $\mathbf{7 0}$ & $\mathbf{1 0 0}$ \\
\hline
\end{tabular}

The table shows responses by respondents whether lecturers are skillful in handling problems in Communication Skills. According to the table, 30 (45\%) students and at the Eastern Technical University and 20 (28\%) students at Njala University, strongly agreed that lecturers are skillful in handling problems in Communication Skills. The table also indicates that 39 (56\%) students and 48 (69\%) students agreed at the Eastern Technical University and Njala University, disagreed. The result according to the respondents shows that in spite of the students' poor performance in communication skills, this lecturer is skillful in handling problems in Communication Skills.

Table 5 Lecturers of communication skills deliver their lessons well

\begin{tabular}{|l|l|l|l|l|}
\hline & Eastern Technical University & \multicolumn{2}{l|}{ Njala University } \\
\hline & No. & $\mathbf{\%}$ & No. & \% \\
\hline Strongly agree & 30 & 43 & 08 & 11 \\
\hline Agree & 38 & 54 & 47 & 67 \\
\hline Disagree & 02 & 3 & 13 & 19 \\
\hline Strongly disagree & - & - & 02 & 3 \\
\hline Total & $\mathbf{7 0}$ & $\mathbf{1 0 0}$ & $\mathbf{7 0}$ & $\mathbf{1 0 0}$ \\
\hline
\end{tabular}

The above table reveals the extent to which lecturers of Communication Skills deliver their lessons well. According to the table, 30 (43\%) students and 8 (11\%) students at the Eastern Technical University and Njala University respectively strongly agreed that lecturers of Communication Skills deliver their lessons well. Also, 38 (54\%) students at the Eastern Technical University and 47 (67\%) students at Njala University agreed. Moreover, at the Eastern Technical University, 02 (3\%) students and 13 (19\%) students at the Njala University disagreed. Finally, 02 (3\%) students from Njala University strongly disagreed. The result of the study, according to the table, reveals that lecturers of Communication Skills deliver their lessons well although a very small number either disagreed or strongly disagreed. 
Table 6 English is spoken by students at all times on campus

\begin{tabular}{|c|c|c|c|c|}
\hline & \multicolumn{2}{|c|}{ Eastern Technical University } & \multicolumn{2}{|c|}{ Njala University } \\
\hline & No. & $\%$ & No. & $\%$ \\
\hline Strongly agree & 01 & 1 & - & - \\
\hline Agree & 15 & 22 & 12 & 17 \\
\hline Disagree & 40 & 57 & 42 & 60 \\
\hline \multirow[t]{2}{*}{ Strongly disagree } & 14 & 20 & 16 & 23 \\
\hline & 70 & 100 & 70 & 100 \\
\hline
\end{tabular}

According to table 6, a greater number of students disagreed that English is spoken by students at all times on campus. From the responses obtained 01 (1\%) students at the Eastern Technical University strongly agree that English is spoken by students at all times on campus. Also, 15(22\%) students and $12(17 \%)$ students at the Eastern Technical University and Njala University respectively agreed, while 40 (57\%) students at the Eastern Technical University and 42 (60\%) students at the Njala University disagree. Finally, 14 (20\%) students and 16 (23\%) students at Eastern Technical University and Njala University, respectively strongly disagree. The result here reveals that English is not spoken by students at all times on campus agreed, while 40 (57\%) students at the Eastern Technical University and 42 (60\%) students at the Njala University disagree. Finally 14 (20\%) students and 16 (23\%) students at the Eastern Technical

University and Njala University, respectively strongly disagree. The result here reveals that English is not spoken by students at all times on campus.

Table 7 English is spoken in your home

\begin{tabular}{|l|l|l|l|l|}
\hline & \multicolumn{2}{|l|}{ Eastern Technical University } & \multicolumn{2}{l|}{ Njala University } \\
\hline & No. & \% & No. & \% \\
\hline Strongly agree & - & - & - & - \\
\hline Agree & 02 & 3 & 03 & 4 \\
\hline Disagree & 10 & 14 & 20 & 29 \\
\hline Strongly disagree & 58 & 83 & 47 & 67 \\
\hline Total & $\mathbf{7 0}$ & $\mathbf{1 0 0}$ & $\mathbf{7 0}$ & $\mathbf{1 0 0}$ \\
\hline
\end{tabular}

Table 7 reveals that English is not spoken in the homes of a greater number of students. According to the table, 02 (3\%) students and 03 (4\%) students at the Eastern Technical University and Njala University respectively agree that English is spoken in their home.

The table further reveals that 10 (14\%) students at the Eastern Technical University and 20(29\%) Njala University, Bo Campus disagreed that English is spoken in their homes. Furthermore, at the Eastern Technical University 58(83\%) students and at Njala University 43 (67\%) students strongly disagreed that English is spoken in their homes.

Table 8 Lecturers teach throughout using English

\begin{tabular}{|c|c|c|c|c|}
\hline & \multicolumn{2}{|c|}{ Eastern Technical University } & \multicolumn{2}{|c|}{ Njala University } \\
\hline & No. & $\%$ & No. & $\%$ \\
\hline Strongly agree & 18 & 26 & 12 & 17 \\
\hline Agree & 40 & 57 & 46 & 66 \\
\hline Disagree & 10 & 14 & 10 & 14 \\
\hline Strongly disagree & 02 & 3 & 02 & 3 \\
\hline Total & 70 & 100 & 70 & 100 \\
\hline
\end{tabular}

The responses to table 8 indicate the statement that lecturers teach throughout using English. The table shows that at the Eastern Technical University 18 (26\%) students and 12 (17\%) students at the Njala University strongly agreed that lecturers teach throughout using English. Also, 40 (57\%) students and 46(66\%) students at the Eastern Technical University and Njala University respectively agreed. However, 10 (14\%) students at the Eastern Technical University and 10 (14\%) at the Njala University disagreed. While $02(3 \%)$ students at the Eastern Technical University and 02 (3\%) students at the Njala University strongly disagreed. 
The result shows that lecturers teach throughout using English although a small percentage reported that lecturers do not teach throughout using English. Such a situation according to the findings has to do with the use of code-switching especially where illustrations or examples are required.

Table 9 There is a compulsory English Language speaking policy in your institution

\begin{tabular}{|c|c|c|c|c|}
\hline & \multicolumn{2}{|c|}{ Eastern Technical University } & \multicolumn{2}{|c|}{ Njala University } \\
\hline & No. & $\%$ & No. & $\%$ \\
\hline Strongly agree & 12 & 17 & 14 & 20 \\
\hline Agree & 34 & 49 & 42 & 60 \\
\hline Disagree & 14 & 20 & 10 & 14 \\
\hline Strongly disagree & 10 & 14 & 04 & 06 \\
\hline Total & 70 & 100 & 70 & 100 \\
\hline
\end{tabular}

According to the table above, (17\%) students at the Eastern Technical University and 14(20\%) students at Njala University strongly agreed that there is a compulsory English Language speaking policy in their respective institutions. Also at the Eastern Technical University, 34 (49\%) students agree while at the Njala University 42 (60\%) students agreed. Moreover, 14 (20\%) students and 10 (14\%) students at Eastern Technical University and Njala University respectively disagreed. The table further reveals that $10(14 \%)$ students at the Eastern Polytechnic and 04(6\%) students at the Njala University strongly disagreed.

According to the result of the table, although there is compulsory English language speaking policies in both institutions, students do not speak English at all times both in the classroom and out of the classroom agreed, while 40 (57\%) students at the Eastern Technical University and 42 (60\%) students at the Njala University disagree. Finally, 14 (20\%) students and 16 (23\%) students at the Eastern Technical University and Njala University respectively strongly disagreed. The result here revealed that English is not spoken by students at all times on campus.

Table 10 Has your institution a general library?

\begin{tabular}{|c|c|c|c|c|}
\hline & \multicolumn{2}{|c|}{ Eastern Technical University } & \multicolumn{2}{|c|}{ Njala University } \\
\hline & No. & $\%$ & No. & $\%$ \\
\hline Yes & 70 & 100 & 70 & 100 \\
\hline No & - & - & - & - \\
\hline Total & 70 & 100 & 70 & 100 \\
\hline
\end{tabular}

According to the table, both Eastern Technical University and Njala University have general libraries. The table indicated $70(100 \%)$ students and 70 (100\%) students at the Eastern Technical University and Njala University respectively. The result revealed that both institutions have libraries and therefore an overwhelming 'yes' response was given.

Table 11 How stocked is your library with English Textbooks

\begin{tabular}{|l|l|l|l|l|}
\hline \multicolumn{2}{|l|}{} & Eastern Technical University & Njala University & \multicolumn{1}{l|}{} \\
\hline & No. & \% & No. & \% \\
\hline Very well stocked & 08 & 11 & 05 & 14 \\
\hline Very stocked & 20 & 29 & 10 & 79 \\
\hline Not very stocked & 42 & 60 & 55 & $\mathbf{1 0 0}$ \\
\hline Total & $\mathbf{7 0}$ & $\mathbf{1 0 0}$ & $\mathbf{7 0}$ & \\
\hline
\end{tabular}

According to table 11, a reasonable number of students responded that their libraries are not really stocked with English textbooks. The table, therefore, shows that at the Eastern Technical University $08(11 \%)$ students reported that their library was very well stocked with English textbooks and at the Njala University 05(7\%) reported that their library was very well stocked with English textbooks.

Also, 20 (29\%) students and 10 (14\%) students at the Eastern Technical University and at the Njala University respectively responded that their libraries were very stocked with English textbooks.

Finally, according to table 11 (60\%) students at the Eastern Technical University and 55 (79\%) students at the Njala University revealed that their libraries are not very well stocked with English textbooks. The result according to the table shows that although both institutions have libraries, these libraries are not very well stocked with English textbooks. 
Table 12 How many periods of communication skills do you have on your teaching timetable?

\begin{tabular}{|l|l|l|l|l|}
\hline & Eastern Technical University & \multicolumn{2}{l|}{ Njala University } \\
\hline & No. & \% & No. & \% \\
\hline 1 Period & 30 & 43 & 30 & 43 \\
\hline 2 Periods & 40 & 57 & 40 & 57 \\
\hline 3 Periods & - & - & - & - \\
\hline 4 Periods & - & - & - & - \\
\hline Total & $\mathbf{7 0}$ & $\mathbf{1 0 0}$ & $\mathbf{7 0}$ & $\mathbf{1 0 0}$ \\
\hline
\end{tabular}

Table 12 shows the number of Communication Skills periods per week for the Higher Teachers (Primary) classes in both institutions. According to the table, 30 (43\%) students from Eastern Technical University and Njala University responded that they have one period of Communication Skills per week. Also, 40 (57\%) students at the Eastern Technical University and another 40 (57\%) students at the Njala University reported that they have two periods of Communication Skills per week on their teaching timetable. The result shows that the Eastern Technical University and Njala University have equal numbers of respondents who reported that they have one period of Communication Skills per week on their teaching timetable. The result further revealed that these categories of respondents are year two students.

The table further explains that Eastern Technical University and Njala University have the same number of respondents who reported that they have two periods of Communication Skills per week on their teaching timetable. The result reveals that this number is composed of year one and year three students. There were 30 years three and 10 years respondents.

Table 13 Are those numbers of periods sufficient to ensure adequate coverage of the syllabus?

\begin{tabular}{|l|l|l|l|l|}
\hline & \multicolumn{2}{|l|}{ Eastern Technical University } & \multicolumn{2}{l|}{ Njala University } \\
\hline & No. & $\mathbf{\%}$ & No. & \% \\
\hline Yes & - & - & - & - \\
\hline No & 70 & 100 & 70 & 100 \\
\hline Total & $\mathbf{7 0}$ & $\mathbf{1 0 0}$ & $\mathbf{7 0}$ & $\mathbf{1 0 0}$ \\
\hline
\end{tabular}

According to the table, all the respondents in both institutions responded that the number of periods allocated for Communication Skills per week is not sufficient. The table indicated 70 (100\%) respondents at the Njala University. The result of this study revealed that the number of teaching periods per week is not sufficient to ensure adequate coverage of the syllabus.

Table 14 Which Aspect (s) of Communication Skills do you Teach?

\begin{tabular}{|l|l|l|l|l|}
\hline & \multicolumn{2}{|l|}{ Eastern Technical University } & \multicolumn{2}{l|}{ Njala University } \\
\hline & No. & \% & No. & \% \\
\hline Grammar and Usage & 01 & 20 & 01 & 20 \\
\hline Reading and Comprehension & 02 & 40 & 01 & 20 \\
\hline Continuous Writing & 02 & 40 & 01 & 20 \\
\hline Summary Writing & - & - & - & - \\
\hline Oral English & - & - & 02 & 40 \\
\hline Total & $\mathbf{0 5}$ & $\mathbf{1 0 0}$ & $\mathbf{0 5}$ & $\mathbf{1 0 0}$ \\
\hline
\end{tabular}

The table above shows the aspects of Communication skills taught by the respondent lecturers in both institutions. According to the table, 01 (20\%) staff respondents at the Eastern Technical

University and 01 (20\%) staff respondents at the Njala University teach Grammar and Usage. Also, 02 (40\%) staff respondents at the Eastern Technical University and 01 (20\%) staff respondents at the Njala University teach Reading and Comprehension. Furthermore, 02 (40\%) staff respondents and 02 (40\%) staff respondents at the Eastern Technical University and the Njala University respectively teach Continuous Writing.

At the Njala University, 01 (20\%) staff respondents teach Oral English. The result revealed that in both institutions there are more lecturers teaching Continuous Writing and Reading Comprehension. This suggests that these two aspects are always challenging in the teaching and learning of Communication Skills 
Table 15 English is spoken by students at all times on campus

\begin{tabular}{|l|l|l|l|l|}
\hline & \multicolumn{2}{|l|}{ Eastern Technical University } & \multicolumn{2}{l|}{ Njala University } \\
\hline & No. & \% & No. & \% \\
\hline Strongly agree & - & - & - & - \\
\hline Agree & - & - & - & - \\
\hline Disagree & 01 & 20 & 02 & 40 \\
\hline Strongly disagree & 04 & 80 & 03 & 60 \\
\hline Total & $\mathbf{0 5}$ & $\mathbf{1 0 0}$ & $\mathbf{0 5}$ & $\mathbf{1 0 0}$ \\
\hline
\end{tabular}

According to the table, 01 (20\%) and 02(40\%) respondents at the Eastern Technical University and Njala University respectively disagreed. Moreover, 04 (80\%) at the Eastern Technical University and 03 (60\%) at the Njala University strongly disagreed that English is spoken by students at all times on Campus.

Table 16 Students Do Not Attend Communication Skills Lessons Regularly

\begin{tabular}{|c|c|c|c|c|}
\hline & \multicolumn{2}{|c|}{ Eastern Technical University } & \multicolumn{2}{|c|}{ Njala University } \\
\hline & No. & $\%$ & No. & $\%$ \\
\hline Strongly agree & 01 & 20 & - & - \\
\hline Agree & 01 & 20 & 04 & 80 \\
\hline Disagree & 03 & 60 & 01 & 20 \\
\hline Strongly disagree & - & - & - & - \\
\hline Total & 05 & 100 & 05 & 100 \\
\hline
\end{tabular}

According to table 01 (20\%) respondents at the Eastern Technical University strongly agreed that students do not attend Communication Skills lessons regularly, while 01 (20\%) respondents and 04 (80\%) respondents at the Eastern Technical University and Njala University respectively agreed. The result further revealed that 03 (60\%) at the Eastern Technical University and 01 (20\%) at the Njala University disagreed. The result shows that students in both institutions do not attend Communication Skills classes regularly.

Table 17 Students are ready to learn Communication Skills

\begin{tabular}{|l|l|l|l|l|}
\hline & \multicolumn{2}{|l|}{ Eastern Technical University } & \multicolumn{2}{l|}{ Njala University } \\
\hline & No. & $\mathbf{\%}$ & No. & \% \\
\hline Strongly agree & - & - & - & - \\
\hline Agree & 01 & 20 & 01 & 20 \\
\hline Disagree & 02 & 40 & 02 & 40 \\
\hline Strongly disagree & 02 & 40 & 02 & 40 \\
\hline Total & $\mathbf{0 5}$ & $\mathbf{1 0 0}$ & $\mathbf{0 5}$ & $\mathbf{1 0 0}$ \\
\hline
\end{tabular}

According to table 17, $01(20 \%)$ staff respondents at the Eastern Technical University and 01 (20\%) staff respondents at Njala University agreed that students are ready to learn Communication Skills. However, 02 (40\%) respondents at the Eastern Technical University and 02 (40\%) at the Njala University disagreed. Finally, at both the Eastern Technical University and the Njala University 02 (40\%) strongly disagreed that students are ready to learn Communication Skills. The result of the study according to the table revealed that a greater number of students are not ready to learn Communication Skills.

Table 18 Students perform well in communication skills

\begin{tabular}{|l|l|l|l|l|}
\hline & Eastern Technical University & \multicolumn{2}{l|}{ Njala University } \\
\hline & No. & \% & No. & \% \\
\hline Strongly agree & - & - & - & - \\
\hline Agree & 01 & 20 & 01 & 20 \\
\hline Disagree & 03 & 60 & 02 & 40 \\
\hline Strongly disagree & 01 & 20 & 02 & 40 \\
\hline Total & $\mathbf{0 5}$ & $\mathbf{1 0 0}$ & $\mathbf{0 5}$ & $\mathbf{1 0 0}$ \\
\hline
\end{tabular}

According to the table, 01 (20\%) respondents at the Eastern Technical University and 01 (20\%) respondents at the Njala University agreed that students perform well in Communication Skills. Also, 03 (60\%) respondents at the Eastern Technical University and 02 (40\%) respondents at the Njala University disagreed. Finally, 01 (20\%) and 02 (40\%) at the Eastern Technical University and Njala 
University respectively strongly disagreed that students perform well in Communication Skills. The performance of the students according to the lecturers is very unsatisfactory. This could be as a result of the lack of interest in the subject and failure to attend lectures regularly

Table 19 which aspects of communication skills do your students find most difficult?

\begin{tabular}{|l|l|l|l|l|}
\hline & \multicolumn{2}{|l|}{ Eastern Technical University } & \multicolumn{2}{l|}{ Njala University } \\
\hline & No. & \% & No. & \% \\
\hline Grammar and Usage & 02 & 40 & 02 & 40 \\
\hline Continuous Writing & 01 & 20 & 02 & 40 \\
\hline Reading and Comprehension & 02 & 40 & 01 & 20 \\
\hline Summary Writing & - & - & - & - \\
\hline Oral English & - & - & 02 & 40 \\
\hline Total & $\mathbf{0 5}$ & $\mathbf{1 0 0}$ & $\mathbf{0 5}$ & $\mathbf{1 0 0}$ \\
\hline
\end{tabular}

According to the table, 02 (40\%) staff respondents from the Eastern Technical University and 02 (40\%) respondents at the Njala University reported that grammar and usage are the most difficult aspects.

Also, 01 (20\%) respondents and 02 (40\%) respondents at the Eastern Technical University and Njala University respectively find Continuous Writing to be the most difficult. The table further shows that 02 (40\%) respondents at the Eastern Technical University and 01 (20\%) respondents at the Njala University reported that Reading and Comprehension is the most difficult aspect. The result of the findings revealed that in both institutions, students find grammar and usage, reading and comprehension, and continuous writing to be the most difficult aspects of Communication Skills

Table 20 Students have negative attitudes towards the learning of communication skills

\begin{tabular}{|l|l|l|l|l|}
\hline & Eastern Technical University & \multicolumn{2}{l|}{ Njala University } \\
\hline & No. & \% & No. & \% \\
\hline Strongly agree & - & - & 01 & 20 \\
\hline Agree & 03 & 60 & 03 & 60 \\
\hline Disagree & 02 & 04 & 01 & 20 \\
\hline Strongly disagree & - & - & - & - \\
\hline Total & $\mathbf{0 5}$ & $\mathbf{1 0 0}$ & $\mathbf{0 5}$ & $\mathbf{1 0 0}$ \\
\hline
\end{tabular}

According to table 01 (20\%), respondents at the Njala University strongly agreed that students have negative attitudes towards the learning of Communication Skills.

Also, 03 (60\%) respondents at the Eastern Technical University and 03 (60\%) respondents at Njala University agreed.

However, 02 (40\%) respondents and 01 (20\%) respondents at the Eastern Technical University and the Njala University respectively disagreed. The result shows that a greater percentage of staff respondents have agreed that students have negative attitudes towards the learning of Communication Skills.

\section{Conclusion and Recommendations}

The following conclusions were obtained after the presentation and analyses of the data for the study:

> That the Higher Teachers Certificate (Primary) students hardly speak English on campus. This has a negative effect on the performance of students in public examinations as well as internal assessments.

$>\quad$ The libraries of both institutions are not very well stocked with English Language textbooks that might facilitate the teaching and learning of Communication Skills.

$>\quad$ Students are not regular in Communication Skills lessons which confirm their negative attitudes towards the learning of Communication Skills. As a result of this students are not fluent in the use of English as they do not much time learning the language.

$>\quad$ That Krio is spoken most often by students in classrooms, around campus, and in their homes. Since students do not speak English frequently, they are not fluent in the language.

$>\quad$ Students find three aspects of Communication Skills to be very difficult. The results of the study revealed that they find grammar and usage, reading and comprehension, and continue writing the most difficult areas.

$>\quad$ The credit hours allocated for the teaching and learning of Communication Skills in both institutions are insufficient. 
Based on the findings of the study, the following recommendations are presented:

The institutions should better enforce compulsory English language speaking policies on both campuses. Therefore, Oral English practice should be emphasized in order to enforce speaking skills.

The excessive use of Krio alongside English should be discouraged and the premium placed on the use of the English language in order to maximize quality performance. Otherwise, the attained standard will diminish. As Phillipson (1992) puts it, 'if other languages are used much, the standard of English will drop'.

Since textbooks are the most often used learning materials in these institutions, the libraries should be better stocked with relevant English Language textbooks that might facilitate the teaching and learning of Communication Skills.

The number of teaching periods for Communication Skills should be increased in order to ensure adequate and timely coverage of the syllabus. Therefore, the teaching periods should be increased from 1 to 2 per week to at least 4,5, or 6 periods per week in order to ensure complete coverage.

Lectures of Communication Skills should apply teaching approaches/methodologies that will help facilitate the effective and efficient teaching and learning of Communication Skills at all levels in the college thereby ensuring that students grasp concepts very easily.

The English Departments of both institutions should establish departmental libraries and have them well stocked with relevant textbooks on Communication Skills.

Funding: The research received no extra funding.

Conflict of Interest: The authors hereby declare that there is no conflict of interest.

\section{References}

[1] Bachman, L. (1990). Fundamental Consideration in Language Testing Oxford: Oxford University Press.

[2] Bright, J.A. (1991). Teaching English as a Second Language. (6 $6^{\text {th }}$ Edition) London, Longman.

[3] Chomsky, N.A. (1968). Language and Mind. New York, Harcourt. Brace and World.

[4] Crystal, D. (1987). The Cambridge Encyclopedia of Language. London, Cambridge University Press

[5] Freeborn D. (1991). An Introduction to the Study of Language. Macmillan, London.

[6] Karimnia, A. and Marziyeh, I. (2007) On Communicative and Linguistics Competence in International Journal of Communication, New Delhi, Bahn. Volume 15, $18-32$.

[7] Leung, C. (2005) Re-contextualizing Communicative Competence in International Journal of Communication, New Delhi, Bahn, 15, 58 - 71

[8] McDonough, S. (2002). Applied Linguistics in Language Education Oxford, University Press

[9] McGregor, G.P. (1991). Teaching English as a Second Language: Theory and Technique for the Secondary Stage, London, Longman

[10] Ornstein, A.C. (1992). Strategies for Effective Teaching New York. Harper and Row

[11] Ozarka, M. (2008). Some suggestions for Academic Writing Instructions at English Teacher Training Colleges, in English Teaching Forum, Washington D.C. Volume 46, Number 1 pages 30-36.

[12] Parke, H. (1992). Child Psychology: A Contemporary View Point. Boston, McGraw-Hill, College,

[13] Phillipson, R. (1992). Linguistics Imperialism. Oxford, University Press.

[14] Sauvignon, S. (1997). Communicative Competence: Theory and classroom Practice: Texts and Contexts in Second Language Learning. (2 ${ }^{\text {nd }}$ Edition), New York, McGraw Hill

[15] Tucker, D.A. (2006). The Impact of Krio on the Learning of English as a Second Language B.Ed. Dissertation, Language Studies Department Faculty of Education and Community Development Studies, Eastern Technical University, Kenema, Sierra Leone, July 2006. 